\title{
SI PADOR (SISTEM PENYEWAAN ALAT OUTDOR) SEBAGAI MEDIA SEWA ALAT OUTDOR BERBASIS WEBSITE STUDI KASUS CV PONDOK PENDAKI Yoki Firmansyah $^{1}$, Reza Maulana ${ }^{2}$,Wahyu Anggara ${ }^{3}$
}

\begin{tabular}{|c|}
\hline Info Artikel \\
\hline $\begin{array}{ll}\text { Diterima } & \text { Desember 10, } 2019 \\
\text { Revisi } & \text { Januari 20, } 2020 \\
\text { Terbit } & \text { Maret 31, 2020 }\end{array}$ \\
\hline $\begin{array}{l}\text { Keywords: } \\
\text { Designing Systems, } \\
\text { Tool Rental, } \\
\text { Website }\end{array}$ \\
\hline
\end{tabular}

\footnotetext{
Identitas Penulis :

Yoki Firmansyah $^{1}$, Reza Maulana ${ }^{2}$, Wahyu Anggara ${ }^{3}$

Universitas Bina Sarana Informatika Program Studi Sistem Informasi Kampus Pontianak ${ }^{1,3}$

Universitas Bina Sarana Informatika Program Studi Sistem Informasi Akuntansi Kampus Pontianak ${ }^{2}$

Jalan Abdurrahman Saleh no. 18 A Pontianak

Email: yoki.yry@bsi.ac.id ${ }^{1}$, reza.rza@bsi.ac.id ${ }^{2}$, jozzwawa70@ gmail.com ${ }^{3}$
}

\section{PENDAHULUAN}

Perkembangan teknologi yang semakin hari semakin meningkat memungkinkan setiap perusahaan untuk berkembang lebih pesat,dimana setiap perusahaan bias mengembangkan system untuk menunjang proses bisnis yang sedang mereka jalankan, salah satu perusahan yang dapat memanfaatkan teknologi adalah cv. Pondok pendaki. $\mathrm{Cv}$ pondok pendaki merupakan perusahaan yang bergerak dibisang jasa sewa menyewa perlengkapan outdor, dimana selama ini proses yang dijalankan belum memanfaatkan teknologi, melainkan dijalankan secara konvensional, dimana penyewa harus mendatangi toko, harus bertransaksi secara langsung dan tidak dapat mengecek ketersediaan barang yang ada, hal ini menyebabkan kurangnya pelanggan kurang tertarik, dan kesulitan, mengingat rata rata pelanggan $\mathrm{CV}$ pondok pendaki berdomisili di luar daerah, maka berdasarkan hasil observasi dan wawancara yang dilakukan dapat ditarik kesimpulan bahwa dibutuhkan sebuah sistem informasi yang dapat menyelesaikan permasalahan tersebut. Dimana sistem informasi ini dapat menjadi fasilitator antara pelanggan dan CV pondok pendaki dalam melakukan transaksi sewa menyewa alat outdor kedepannya, dan diutuskanlah sistem informasi tersebut diberi nama SIPADOR atau sistem informasi penyewaaan alat outdoor. Sistem adalah suatu jaringan prosedur yang dibuat menurut pola yang terpadu untuk melaksanakan kegiatan pokok perusahaan [1]. Pengamat lain mengatakan sistem dapat diartikan sebagai satu kesatuan yang terdiri dari komponen- komponen atau subsistem yang tertata dengan teratur, saling interaksi, saling ketergantungan satu dengan yang lainnya, dan tidak dapat dipisahkan (integratif) untuk mewujudkan suatu tujuan [2] , sedangkan yang dimaksud dengan sistem informasi merupakan sebuah jaringan kerja yang saling terhubung dan bekerja sama untuk mencapai sebuah tujuan dan biasanya terjadi pertukaran informasi dalam proses penyelesaianya [3].

Sistem informasi yang diberi nama sistem informasi penyewaan alat outdor atau SI PADOR dibuat dengan berbasis website, website Sekumpulan halaman yang terdiri dari beberapa halaman yang berisi informasi dalam bentuk data digital baik berupa text, gambar, video, audio, dan animasi lainnya yang disediakan melalui jalur koneksi internet [4] website sendiri merupakan sebuah halaman yang dapat dilihat dengan web browser, Web Browser adalah aplikasi perangkat lunakyang digunakan untuk mengambil dan menyajikan sumber informasi web[5], pendapat lain mengatakan web browser adalah alat yang digunakan untuk melihat halaman web [6]. Bahasa pemrograman yang akan digunakan untuk SIPADOR yaitu menggunakan bahasa HTML, merupakan singkatan dari Hypertext Markup Language dan berguna untuk menampilkan halaman web [6], pendapat lain mengatakan HTML adalah medium yang selalu dikirimkan ke web browser baik halaman itu berupa halaman statis, sebuah script (seperti PHP), ataupun yang dibuat oleh program CGI (Common Gateway Interface) [7], Selain HTML Digunakan Pula bahasa PHP, PHP adalah 
(Hypertext Preprocessor) adalah bahasa pemrograman web berupa script yang dapat diintegrasikan dengan HTML [6].

Selain menggunakan bahasa pemrograman PHP dan HTML untuk mmembuat SI PADOR juga menggunakan database, dimana data base dibangun dengan memanfaatkan MySQL . MySQL adalah salah satu jenis database server yang menggunakan SQL sebagai bahasa dasar untuk mengakses database nya. Dengan menggunakan script PHP dan PERL Software database ini dapat berfungsi atau berjalan pada semua platform sistem operasi yang biasa digunakan (Windows, Linux, OS/2, berbagai varian Unix).[7] dan untuk tahap desain akan di tuangkan kedalam UML (Unified Modeling Language). UML (Unified Modelling Language) merupakan bahasa visual untuk pemodelan dan komunikasi mengenai sebuah sistem dengan menggunakan diagram dan teks-teks pendukung [8], dimana didalam UML sendiri ada beberapa diagram yang akan dipergunakan, diantaranya use case diagram \& activity diagram, Use case diagram merupakan pemodelan untuk kelakuakn (behavior) sistem informasi yang akan dibuat. Use case digunakan untuk mengetahui fungsi apa saja yang ada di dalam sistem informasi dan siapa saja yang berhak menggunakan fungsi-fungsi tersebut [9], Diagram aktivitas atau activity diagram menggambarkan workflow (aliran kerja) atau aktivitas dari sebuah sistem atau proses bisnis atau menu yang ada pada perangkat lunak [10].

\section{METODE}

\subsection{Metode Pengembangan Perangkat Lunak}

SI PADOR akan dibuat berdasarkan metode prototyping, Model prototyping merupakan suatu teknik untuk mengumpulkan informasi tertentu mengenai kebutuhan-kebutuhan informasi pengguna secara cepat. Berfokus pada penyajian dari aspek-aspek perangkat lunak tersebut yang akan nampak bagi pelanggan atau pemakai. Prototipe tersebut akan dievaluasi oleh pelanggan/pemakai dan dipakai untuk menyaring kebutuhan pengembangan perangkat lunak.[11] sedangkan pendapat lain mengatakan prototyping merupakan metode pengembangan perangat lunak, yang berupa model fisik kerja sistem dan berfungsi sebagai versi awal dari sistem. Dengan metode prototyping ini akan dihasilkan prototype sistem sebagai perantara pengembang dan pengguna agar dapat berinteraksi dalam proses kegiatan pengembangan sistem informasi. Agar proses pembuatan prototype ini berhasil dengan baik adalah dengan mendefinisikan aturan-aturan pada tahap awal, yaitu pengembang dan penguna harus satu pemahaman bahwa prototype dibangun untuk mendefinisikan kebutuhan awal. Prototype akan dihilangkan atau ditambahkan pada bagiannya sehingga sesuai dengan perencanaan dan analisis yang dilakukan oleh pengembang sampai dengan ujicoba dilakukan secara simultan seiiring dengan proses pengembangan [12]

Model prototype ini memiliki beberapa tahapan[10], yaitu:

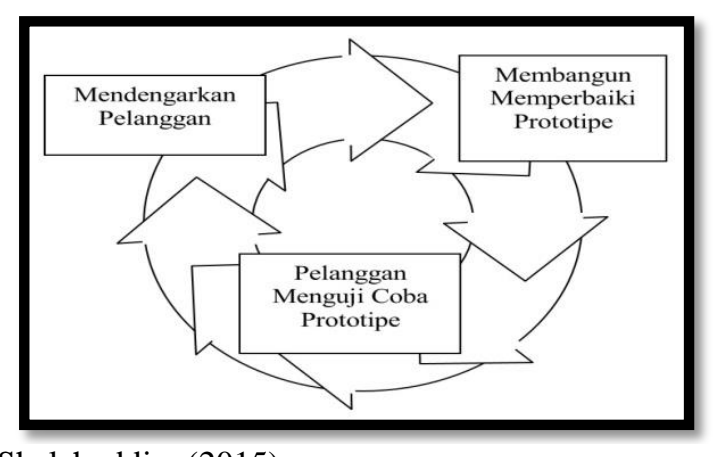

Sumber : Sukamto \& Shalahuddin, (2015)

Gambar 1. Model Prototype

1. Mendengarkan Pelanggan

Tahap pertama dari model Prototipe adalah mendengarkan pelanggan, dimana dalam tahap ini peneliti melakukan beberapa teknik yaitu observasi dan wawancara, untuk mendengarkan pelanggan. Adapun yang dimaksud dengan pelanggan disini adalah objek penelitian yaitu CV Pondok Pendaki, dan setelah dilakukan wawancara dan observasi maka ditemukanlah permasalahan pokok yang dihadapi yang sudatertuang pada bagian pendahuluan, selain mendapatkan permasalahan dalam tahap pertama ini akhirnya juga ditentukan solusi dari permasalahan, yaitu membuat sebuah system informasi Penyewaan alat Outdor yang diberi nama Sipador, beserta apa saja kebutuhan dari system tersebut, dan apa harapan dari CV Pondok Pendaki terkait fitur dan apa yang bisa dilakukan oleh SIPADOR dimana sebelum mendapatkan solusi maka diperlukan juga analisa system yang sedang terjadi di CV pondok pendaki, setelah mendapatkan analisa system yang sedang berjalan maka akan lebih mudah menemukan solusi dari permasalahan yang ada 
2. Membangun dan memperbaiki prototype

Setelah mendengarkan pelanggan, terkait permasalahan dan solusi apa yang diharapkan oleh pelanggan di tahap satu berikutnya yaitu membangun dan memperbaiki prototype aplikasi SIPADOR, dimana pada tahap ini mulai dibangun beberapa rancangan dari aplikasi, rancangan rancangan aplikasi yang dibangun menggunakan diagram UML, yaitu diagram use case, diagram activity dan prototype dari aplikasi SI PADOR

3. Pelanggan Menguji Coba Prototipe

Setelah aplikasi dibangun, dan diperbaiki maka berikutnya adalah melakukan uji coba, dimana SIPADOR akan langsung diujicobakan oleh pelanggan, adapun metode pengujian yang digunakan adalah menggunakan metode blackbox testing, blackbox testing atau yang biasa disebut dengan pengujian kotak hitam dilakukan dengan membuat kasus uji yang bersifat mencoba semua fungsi dengan memakai perangkat lunak apakah sesuai dengan spesifikasi yang dibutuhkan[10] sedangkan pendapat lain mengatakan BlackBoxTesting terfokus pada unit program apakah memenuhi kebutuhan(requirment)". Pada Balck box testing, cara pengujian hanya dilakukan dengan menjalankan atau mengeksekusi unit atau modul, kemudian mengamati apakah hasil unit sesuai dengan yang diinginkan. [13]

\subsection{Metode Pengumpulan Data}

Didalam proses melaksanakan penelitian, pengumpulan data mutlak harus dilakukan, dimana data yang didapatkan akan mendukung proses penelitian lebih lanjut, adapun teknik pengumpulan data yang digunakan dalam penelitian ini adalah sebagai berikut

1. Wawancara

Untuk menggali permasalahan yang ada pada objek, langkah pertama yang dilakukan penulis adalah melakukan wawancara kepada pemilik CV Pondok Pendaki, yang mana dari wawancara ini ditemukanlah beberapa permasalahan yang membutuhkan solusi, selain untuk mengetahui permasalahan dan solusi wawancara juga dilakukan untuk mendengarkan apa saja keinginan pemilik CV Pondok Pendaki terkait fitur apa yang akan di sematkan pada SIPADOR dan ini berkaitan dengan tahapan pengembangan system pada bagian mendengarkan pelanggan, data data yang didapatkan dari wawancara akan dipergunakan sebagai bahan untuk membangun Sistem Informasi Penyewaan Alat Outdor (SIPADOR)

2. Observasi

Setelah melakukan wawancara pada pemilik dan meminta izin, peneliti melanjutkan mengumpulkan data dengan cara melakukan observasi, observasi dilakukan untuk melihat secara langsung permasalahan yang terjadi dilapangan, sehingga lebih memudahkan untuk menyusun konsep mendapatkan solusi, pada saat observasi peneliti melihat secara langsung prosedur yang sedang berjalan, serta dapat memetakan permasalahan serta prioritas pekerjaan yang harus dilakukan untuk mencapai solusi dari permasalahan yang ada

3. Studi Pustaka

Selain melakukan wawancara dan observasi penulis juga melakukan pengumpulan data melalui studi pustaka, hal ini terkait untuk mencari referensi referensi yang relevan dengan penelitian, beberapa referensi didapatkan dari jurnal, ataupun artikel ilmiah, hingga buku buku referensi yang berbasis cetak maupun online

\section{HASIL}

Hasil dari penelitian ini adalah sebuah Sistem Informasi Penyewaan Alat Outdor yang diberi nama SIPADOR, dimana sistem informasi ini akan membantu CV Pondok Pendaki dalam menyelesaikan permasalahan yang terkait sewa menyewa alat outdor. Dan seperti yang telah dibahas sebelumnya bahwa metode pengembangan perangkat lunak yang digunakan adalah model prototyping maka dari itu hasil dari penelitian ini juga akan mengikuti langkah lakah dari model prototyping tersebut.

Adapun penjelasan dari masing masing langkah yaitu sebagai berikut :

\subsection{Mendengarkan Pelanggan}

Ada beberapa hasil yang didapatkan dari mendengarkan pelanggan, dalam hal ini adalah CV Pondok Pendaki 
1. Prosedur Sistem berjalan

Berdasarkan hasil observasi dan wawancara yang dilakukan didapat beberapa prosedur sistem yang sedang berjalan terkait penyewaan alat outdoor pada CV Pondok pendaki yaitu sebagai berikuti

a. Prosedur Penyewaan Penyewaan

Konsumen menghubungi sales dengan via whatsapp untuk melakukan pemesanan. Kemudian konsumen menanyakan tentang barang yang akan disewa. Setelah itu pihak sales menjelaskan tentang barang yang akan disewa oleh konsumen dan melakukan pengecekan ketersediaan barang. Jika konsumen setuju maka sales akan membuatkan bon pembayaran dan menyiapkan barang-barang yang telah disewa konsumen yang nantinya barang tersebut akan diserahkan kepada kurir untuk segera diserahkan kepada konsumen. Apabila penyewaan tersebut dibatalkan maka semua kesepakatan yang telah dibicarakan akan dibatalkan juga.

b. Prosedur Pembayaran

Kurir membawa barang-barang yang telah disewa oleh konsumen beserta dengan bon pembayaran untuk diserahkan dan ditandatangani oleh konsumen. Konsumen menerima bon dan menandatangani bon pembayaran tersebut. Kemudian konsumen menyerahkan uang pembayaran dan menyerahkan kembali bon pembayaran yang sudah di tandatangani. Apabila kurir telah menerima bon pembayaran yang telah ditandatangani oleh konsumen maka kurir akan memberikan barang-barang yang telah disewa oleh konsumen.

c. Prosedur Laporan

Kurir menyerahkan bon pembayaran yang telah ditandatangani konsumen beserta uang pembayaran kepada admin. Kemudian admin menerima bon pembayaran tersebut dan merekap data pembayaran penyewaan barang. Kemudian admin membuat laporan bulanan. Setelah itu admin menyerahkan laporan bulanan kepada manager. Kemudian manager menerima laporan bulanan tersebut.

2. Diagram Activity Prosedur Sistem Berjalan

Berdasarkan dari prosedur sistem berjalan berikutnya dibuatlah diagram activity prosedur sistem berjalan agar dapat memudahkan dalam menemukan permasalahan

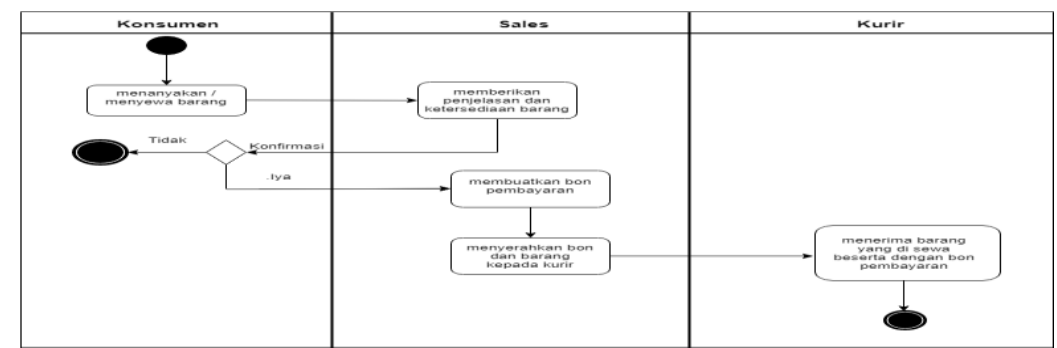

Sumber : hasil wawancara dan Observasi (2019)

Gambar 2. Diagram Acvitity Penyewaan Barang

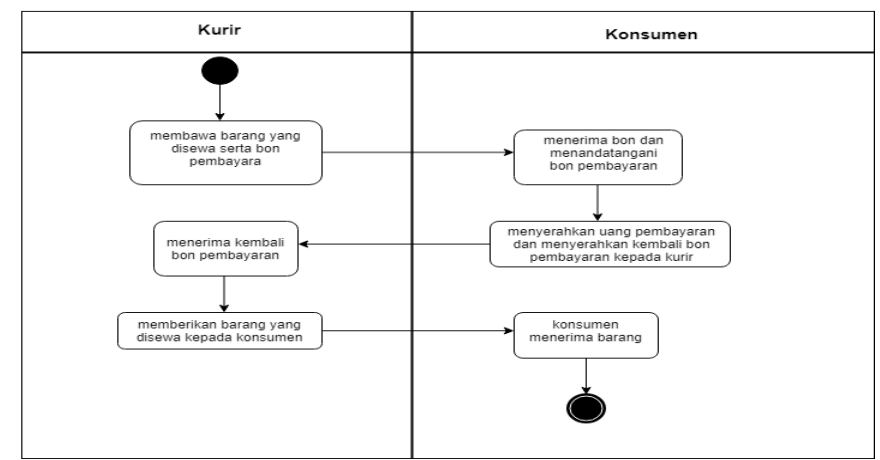

Sumber : hasil wawancara dan Observasi (2019)

Gambar 3. Diagram Acvitity Proses Pembayaran sewa alat outdoor 


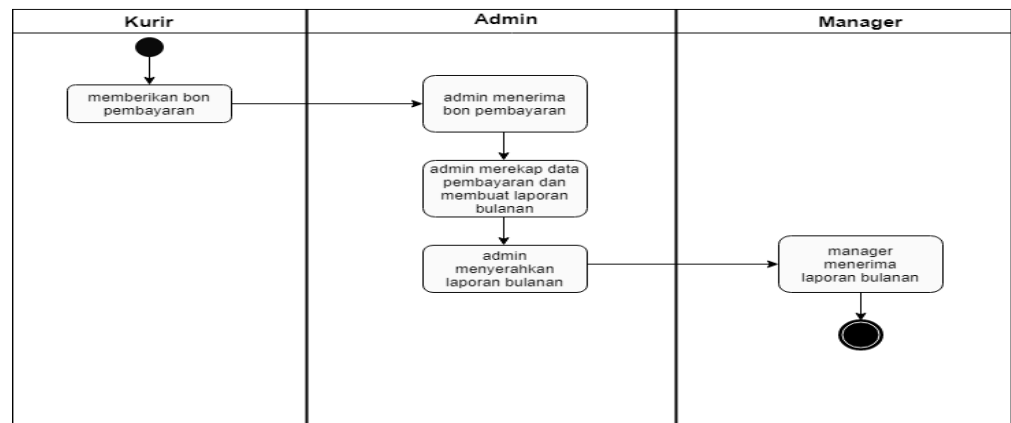

Sumber : hasil wawancara dan Observasi (2019)

Gambar 4. Diagram Acvitity Proses Laporan Penyewaan

3. Permasalahan Pokok CV Pondok Pendaki

4. Untuk masalah pencatatan pesanan penyewaan sering teradi salah pencacatan pesanan dikarenakan menggunakan catat tangan, data ini rentan akan kerusakan dan manipulasi data dan juga sering terjadi salah tulis lokasi pengantaran barang yang disewa oleh konsumen.

5. Permasalahan komunikasi antara karyawan sering teradi miss komunikasi, hal ini berakiba kepada kinera karyawan yang menjadi hambat karena karyawan harus mengkonfirmasi ulang informasi yang disampaikan.

6. Untuk sistem pembuatan laporan maka admin harus merekap data pesanan konsumen satu persatu, hal ini akan memakan waktu yang lama dan data yang disajikan kurang akurat.

7. Pemecahan Masalah

8. Untuk menangani permasalahan salah pencatatan pesanan penyewaan barang maka disarankan membangun sistem yang terkomputerisasi dan mengkonfirmasi ulang pesanan tersebut kepada konsumen.

9. Untuk sistem pembuatan laporan yang harus merekap satu persatu data penyewaan barang yang dipesan oleh konsumen maka disarankan membangun sebuah sistem yang terkomputerisasi yang dapat membuat laporan bulanan agar tidak memakan waktu yang lama dan keakuratan data tidak diragukan.

10. Analisa Kebutuhan Perangkat Lunak

Setelah menjabarkan permasalahan, dan mengetahui solusi bahwa cv pondok pendaki membutuhkan sebuah Sistem informasi penyewaan, maka dari itu berikutnya yaitu menganalisa kebutuhan dari aplikasi dilihat dari sisi user dan sistem, dimana nantinya akan ada dua user, yaitu admin dan pengguna, dan kebutuhan nya adalah sebagai berikut :

11. Kebutuhan admin

Admin adalah user yang mengeola bagian backend aplikasi, dimana nantinya admin dapat melakukan beberapa tindakan terhadap aplikasi yaitu mengelola produk, mengelola data penyewa, mengkonfirmasi penyewaan, dan mengakses laporan penyewaan

12. Kebutuhan Konsumen

Kebutuhan konsumen merupakan kebutuhan dari konsumen ataupun penyewa pad acv pondok pendaki, dimana konsumen nantinya akan diberikan beberapa fitur diantaranya yaitu dapat melakukan pemesanan, dapat melengkapi data penyewaan, dapat mengelola data pribadi dan dapat melakukan pembayaran melalui aplikasi SIPADOR

13. Kebutuhan sistem

Dari sisi aplikasi sendiri nantinya pengguna baik admin atau konsumen dapat melakukan login dan login pada halaman masing masing, serta dapat melakukan logout, serta menampilkan informasi informasi yang berguna bagi user, baik itu admin maupun konsumen

3.2. Membangun prototype

Setelah mendapatkan kebutuhan, mengetahui permasalahan maka langkah berikutnya adalah membangun prototype dari Sistem Informasi penyewaan alat outdor atau dipador, adapun beberapa tampilan dari sipador adalah sebagai berikut : 
Tampilan Aplikasi SIPADOR

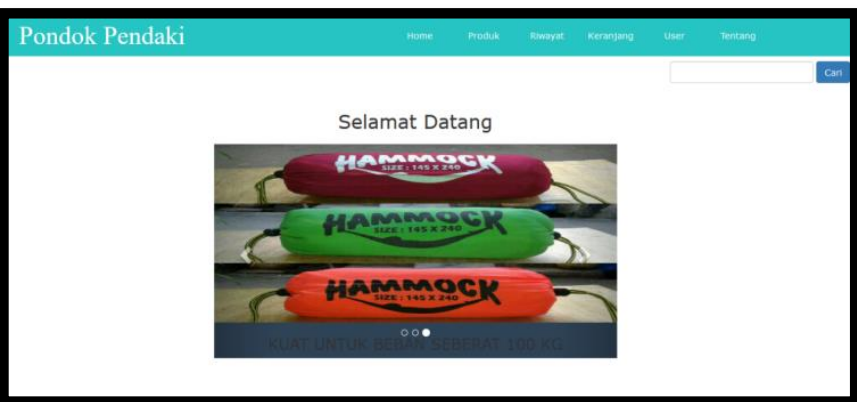

Sumber: Hasil Penelitian (2019)

Gambar 5. Halaman utama menu Pelanggan
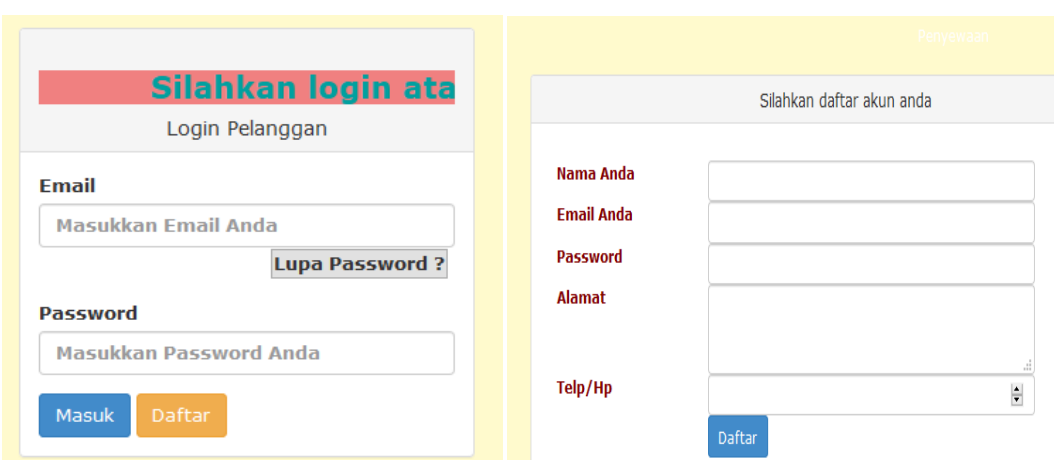

Sumber: Hasil Penelitian (2019)

Gambar 6. Halaman Login dan Halaman Pendaftaran

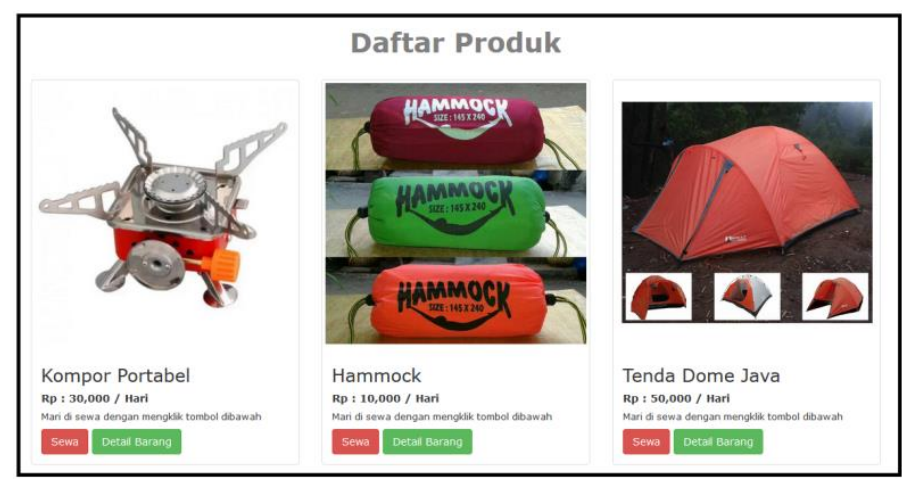

Sumber: Hasil Penelitian (2019)

Gambar 8. Halaman Menu Produk

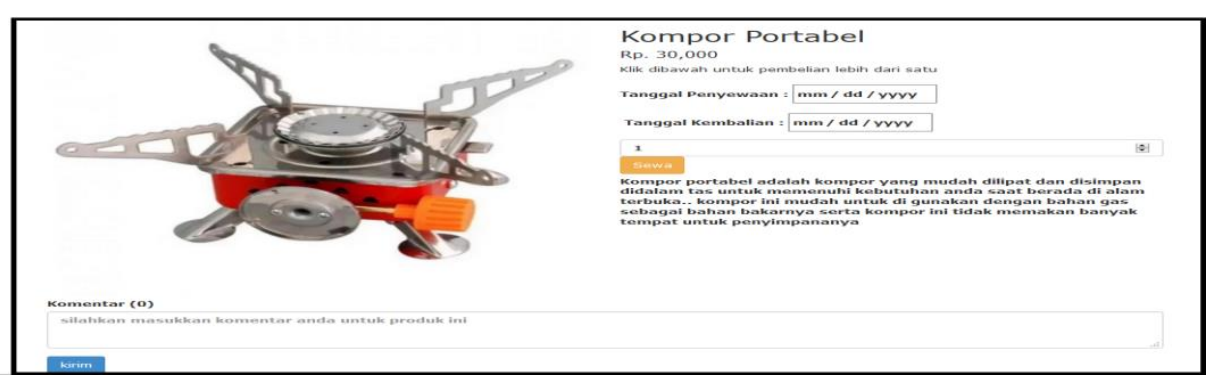


Sumber: Hasil Penelitian (2019)

Gambar 9. Halaman detail produk

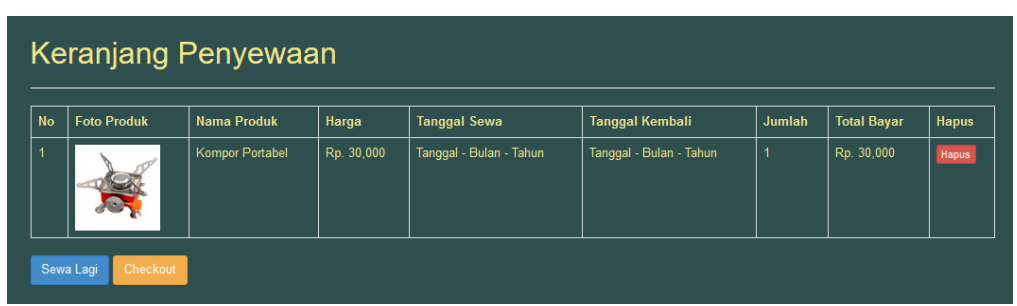

Sumber: Hasil Penelitian (2019)

Gambar 10. tampilan keranjang penyewaan

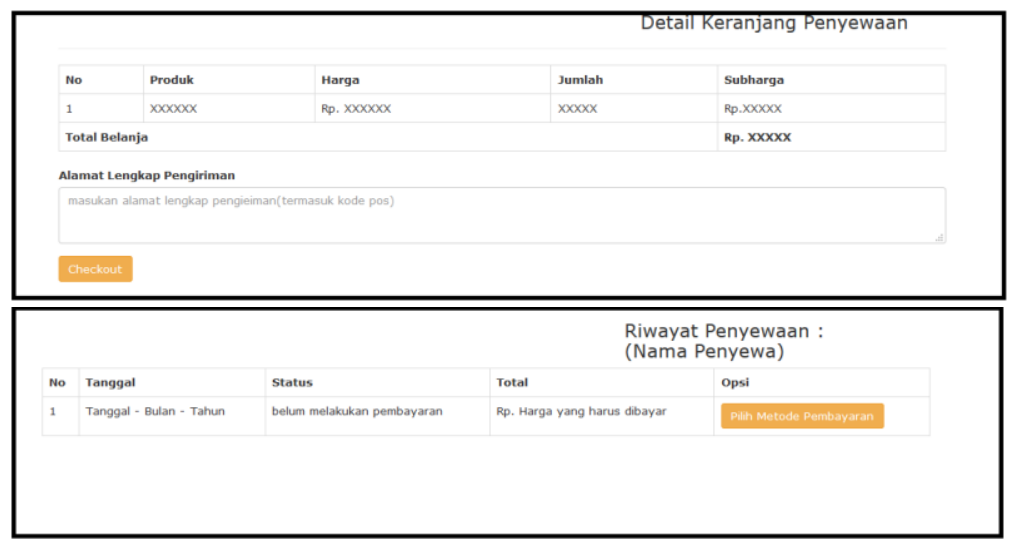

Sumber: Hasil Penelitian (2019)

Gambar 11. Tampilan detail keranjang penyewaan \& Riwayat Penyewaan

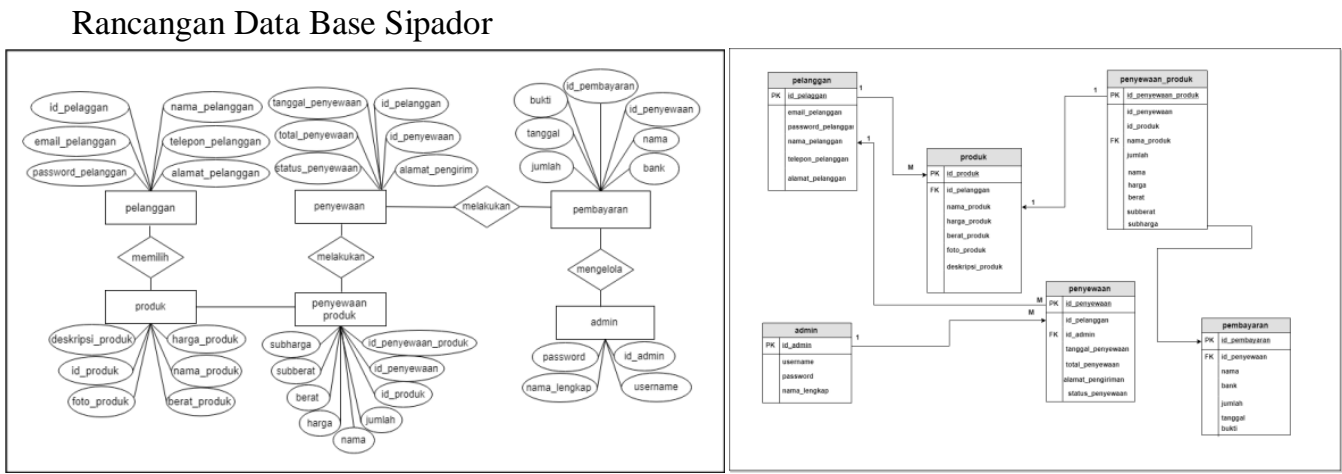

Sumber: Hasil Penelitian (2019)

Gambar 12. Rancangan diagram ERD \& LRS SIPADOR

Diagram USE CASE SIPADOR 


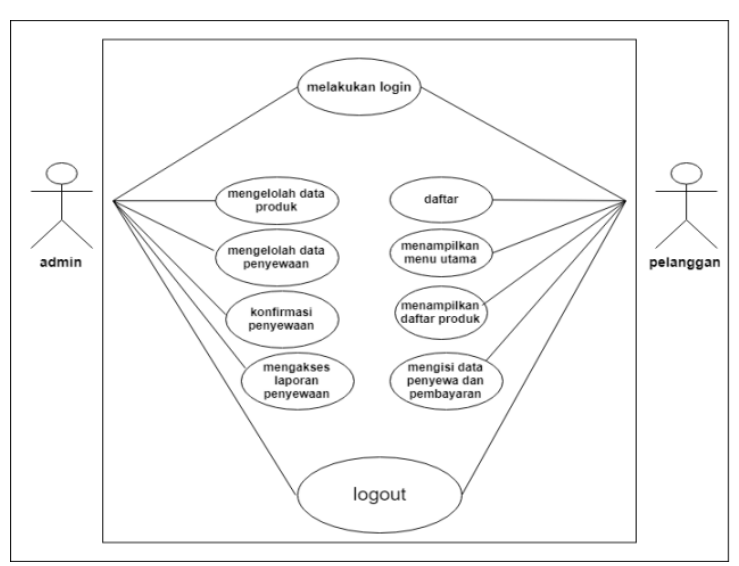

Sumber: Hasil Penelitian (2019)

Gambar 13. Diagram USE CASE SIPADOR

\section{KESIMPULAN}

Beberapa kesimpulan yang dapat diambil dari penelitian ini adalah sebagai berikut. Dengan adanya aplikasi berbasis website ini pihak CV. Pondok Pendaki dapat melakukan pengelolaan data dengan mudah dan cepat, serta dapat meminimalisir kesalahan pada pengelolaan data tersebut. Data-data atau informasi yang dihasilkan dari prosedur sistem berjalan akan disimpan pada satu basis data dan dapat di bac-up setiap saat, sehingga penyimpana data akan lebih aman. Dengan adanya sistem berbasis website ini, diharapkan pemasaran menjadi lebih luas, dan memudahkan pelanggan dalam melakukan pemesanan. SIPADOR masih dapat dikembangkan, tidak hanya untuk penyewaan saja, melainkan dapat membantu permasalahan permasalahan yang terdapat pada CV Pondok Pendaki

\section{UCAPAN TERIMA KASIH}

dengan terselesaikannya penelitian ini maka peneliti mengucapkan terima kasih yang sebesar besarnya kepada CV Pondok pendaki serta rekan rekan yang membantu mulai dari observasi wawancara, pengumpulan data hingga terciptanya SIPADOR

\section{REFERENSI}

[1] W. Mulyani and B. E. Purnama, "Pembangunan Sistem Informasi Data Balita Pada Posyandu Desa Ploso Kecamatan Punung Kabupaten Pacitan," Speed - Sentra Penelit. Eng. dan Edukasi, vol. 7, no. 2, pp. 15-19, 2013.

[2] M. S. Dr. Kusnendi, “Konsep Dasar Sistem Informasi," in Konsep Dasar Sistem Informasi, 2014, pp. 1-36.

[3] Y. Firmansyah and Udi, "Penerapan Metode SDLC Waterfall Dalam Pembuatan Sistem Informasi Akademik," J. Teknol. Manaj. Inform., vol. 4, no. 1, pp. 184-191, 2018.

[4] M. Destiningrum and Q. J. Adrian, "Sistem Informasi Penjadwalan Dokter Berbassis Web Dengan Menggunakan Framework Codeigniter," Teknoinfo, vol. 11, no. 2, pp. 30-37, 2017.

[5] R. A. Sagita and H. Sugiarto, "Penerapan Metode Waterfall Pada Sistem Informasi Penjualan Furniture Berbasis Web,” Indones. J. Netw. Secur., vol. 5, no. 4, pp. 1-7, 2016.

[6] P. Agus and Y. Safitri, "Pemanfaatan Sistem Informasi Perpustakaan Digital Berbasis Website Untuk," Indones. J. Softw. Eng., vol. 1, no. 1, pp. 1-10, 2015.

[7] M. Susanti, "Perancangan Sistem Informasi Akademik Berbasis Web Pada Smk Pasar Minggu Jakarta," J. Informatika, vol. 3, no. 1, pp. 91-99, 2016.

[8] B. Sudrajat, "Rancang Bangun Sistem Informasi Penjualan,” Interkom, vol. 3, no. 2, pp. 76-93, 2018.

[9] W. Gata and Grace, "Pemodelan UML sistem informasi Monitoring Penjualan dan stok barang," Pemodelan Uml Sist. Inf. Monit. Penjualan Dan Stok Barang (Studi Kasus Distro Zhezha Pontianak), vol. IV, no. 2, pp. 107-116, 2016, doi: 10.2135/cropsci1983.0011183X002300020002x.

[10] R. A. Sukamto and M. Shalahuddin, Kolaborasi Rekayasa Perangkat Lunak Terstruktur dan Berorientasi Objek. Bandung: Informatika, 2015.

[11] R. Susanto and A. D. Andriana, "Perbandingan Model Waterfall Dan Prototyping Untuk Pengembangan Sistem Informasi," Maj. Ilm. UNIKOM, vol. 14, no. 1, pp. 41-46, 2016, doi: 10.34010/miu.v14i1.174.

[12] D. Purnomo, "Model Prototyping Pada Pengembangan Sistem Informasi," JIMP - J. Inform. Merdeka Pasuruan, vol. 2, no. 2, pp. 54-61, 2017.

[13] M. S. Maulana, "PERANCANGAN DAN PENGEMBANGAN APLIKASI WEB PENJUALAN (Studi Kasus : CV. Herson Mitra Solusindo)," J. Khatulistiwa Inform., vol. vol 2, no. no 2, pp. 175-183, 2014. 